\title{
Integration of Suppliers and Manufacturers within Construction Supply Chains through Innovative Procurement Strategies
}

\author{
Malik M. Khalfan, Mohammed Arif and Hani M. Aburas \\ Salford Centre for Research and Innovation, University of Salford, \\ Greater Manchester, United Kingdom, and Department of \\ Industrial Engineering, Faculty of Engineering, \\ King Abdulaziz University Jeddah, Saudi Arabia \\ m.m.a.Khalfan@Salford.ac.uk
}

\begin{abstract}
Recent innovative initiatives within the public sector construction procurement are challenging traditional, non-relational ways of procuring construction projects. The new concepts and practices involved in innovative procurement methods for construction are intended to empower clients to exercise more control over the supply chain and generate more co-operation among project participants. The initiatives aim to: bring project members closer together; integrate the supply chain; create greater trust; develop relationships on a long term basis; introduce a pain and gain culture; and reuse the knowledge on succeeding projects. This paper, with examples from the UK construction industry, presents ways clients are currently exercising their roles in order to integrate the downstream supply chain members, including suppliers and manufacturers of products. This paper particularly highlights the benefits of, and the motivation towards innovative procurement resulting into integration of downstream supply chain members through two case studies, done as part of a supply chain integration project at the Salford Centre for Research and Innovation (SCRI). The case studies demonstrate how organisations involved have promoted innovative thinking across the supply chain through innovative procurement. The case studies also highlight some of the critical factors in integrating suppliers and manufacturers at the beginning of any project. The paper concludes that through clients' initiatives, there is a great potential to utilise expertise and knowledge of suppliers and manufacturers at the outset of a project, in order to achieve effective planning and delivery of the
\end{abstract}


whole project, as well as greater integration among supply chain members working on the project.

Keywords: Procurement Strategies, Supply Chain Integration, Suppliers and Manufacturers, Construction Industry, Clients.

\section{Introduction}

The UK construction industry has seen many improvement strategies recently incorporated within the public policy documents. Some of the strategies from these policy documents have challenged the traditional ways of construction procurement generally and introduced the new and innovative methods including partnering, private finance initiatives (PFI), project alliances, framework agreements, prime contracting, ... etc. ${ }^{[1-2]}$. Some recommendations included within these policy documents focus on the integration of suppliers and manufacturers within the supply chain and building long term relationships with them. Other discussion in the same context include: impact of information of upcoming projects from clients in order to facilitate work load smoothing by suppliers and manufacturers; the use of Information and Communication Technology (ICT) including use of e-procurement system to enhance efficiency; supplier and manufacturer capacity in response to the demands from clients; early involvement of suppliers and manufacturers to gain their knowledge and experiences through innovative procurement routes ${ }^{[3-5]}$.

Despite growing realization among forward looking clients and contractors, the establishment of innovative procurement systems and processes are still at their infancy. The paper discusses the concept of innovative procurement within construction industry and presents two case studies, showing how leading public sector clients have established innovative procurement processes and thinking, in order to integrate the downstream construction supply chain members; especially suppliers and manufacturers of products. The case studies offer learning opportunities for other client organizations both public and private sectors, who are seeking to establish innovative procurement routes to integrate their supply chains. The paper concludes that through clients' initiatives, there is a great potential to integrate downstream supply chain members on a construction project; especially suppliers and manufacturers. Their expertise and knowledge can be utilized at the outset of the project, 
resulting in effective planning and management of interfaces during the project as well as delivery of the whole project.

\section{Innovative Procurement}

Latham $^{[6]}$ and $\operatorname{Egan}^{[7-8]}$ lead the efforts to promote innovation in the construction sector. As a result of the Egan Report ${ }^{[7]}$, the Movement for Innovation (M4I) came into existence. M4I has helped companies within the industry to realize the importance of innovation, and encouraged them to come up with innovative ways of dealing with procurement related issues. The public sector has been seen to embrace new procurement methods based on partnering concepts in recent years, following the above mentioned reports and strategy documents such as Achieving Excellence ${ }^{[9]}$, and direction from both the Office of Government Commerce ${ }^{[10]}$ and the National Audit Office ${ }^{[11]}$.

The National Audit Office has identified new procurement routes based on partnering approaches, as a key tool in delivering better public projects $^{[11]}$. The report presented the picture of the UK construction industry by saying: Client expectations are too low; $75 \%$ of projects go over budget; and $66 \%$ are delivered late. The report also confirmed that projects awarded on lowest price rarely if ever, provided good value. It also emphasized that the public clients must specify needs, not solutions, in their tendering documents, and also should form long term relationships with suppliers and manufacturers, which are selected based on their capability and capacity. Following the report, was a the release of data suggesting that innovative procurement approaches, which tend to encourage partnering and supply chain integration, had a demonstrable benefit within the public sector ${ }^{[12]}$.

Through Achieving Excellence ${ }^{[9]}$, the Government had already committed all government departments:

- To work with industry to reduce waste in all aspects of construction procurement and management;

- To enter into co-operative relationships with their suppliers to ensure an open and mutually productive environment, and

- To ensure an integrated supply chain.

One of the main purposes of the government push towards abovementioned new partnering arrangements is to motivate organizations 
within the construction industry to take advantages of the long term relationships with public clients that would result in, not only business benefits for them, but a better performing industry ${ }^{[13-14]}$.

In order to study the changes occurring within the industry, the introduction of innovative ways of procuring the construction works, the potential benefits and bottlenecks experienced during the whole process, and changes within organizational cultures and personal attitudes; the SCRI Research Centre is carrying out a research project titled "The Supply Chain Integration Project". The project is to investigate the changes that are occurring in the supply of consultancy, contracting services, and products in response to clients' innovative procurement initiatives. The main aim of this research proposal is to determine if there are ways of integrating the supply chain that will ensure service and product quality whilst still supporting the government and client initiatives, with an overall aim of increasing the competitiveness of the construction sector.

Literature confirms that there is a gradually increasing recognition that suppliers and subcontractors should also be involved ${ }^{[15-16]}$. Many authors argue for such a broad partnering approach. All key actors whose activities influence the overall project performance should be included in the partnering team and the incentive schemes ${ }^{[17-20]}$. A change towards increased integration among different supply chain partners through supply chain management should be driven by clients for two main reasons. First, clients often seem more enthusiastic than the main contractors about retaining other supply chain members' experiences ${ }^{[21]}$. Since, clients can appreciate value creation more than main contractors, where profitability comes through low costs. Secondly, the relationship between the main contractor and other members is affected by the relationship between client and main contractor ${ }^{[22-23]}$. Hence, the client's procurement procedures, including client recommendation and nomination of subcontractors, suppliers and manufacturers to main contractors, will heavily affect supply chain integration ${ }^{[21,24]}$. To achieve a change towards more collaborative relationships among supply chain participants, the clients' procurement behavior is therefore critical ${ }^{[22]}$. Findings from the case studies reveal clearly that the clients need to be committed to promote such culture and should lead the newer way of working and thinking. Mentioned below are quotes from a material 
supplier and a manufacturer, showing the importance of clients' initiative in order to integrate the entire supply chain:

'It is UK's culture: How Cheap in price? The UK contractors are having the same culture. They do not know what partnering is, and they do not know how work is done, how things are installed, they do not explain to customers how to use the facilities and other different installations which then result into additional journey by the installation team... The change in the thinking of main contractor has to, and will come from clients. Clients need to take a lead in the whole process.' (Construction Product Manufacturer).

'While selecting the products, clients now look at stock availability, commitment of services level, whole life cost, ... etc. But in the past, when contractors used to select the products, it was based on the cheapest price; rebate; product supplier who gives more and longer period credit'... etc' (Construction Product Supplier).

The next sections discuss the findings in more detail within the case studies and give suppliers and manufacturers perspective on the integration.

\section{Case Studies}

\subsection{Methodology}

The case study research methodology has been adopted for this paper. The case studies uncover the perceptions of firms within the construction industry with regard to the existing partnering arrangements they currently undertake. The methodology used multiple approaches to collect qualitative and quantitative data. Basic quantitative data and company documentation were used to provide research context through content analysis while qualitative data was collected in the form of a number of unstructured interviews during the case studies, sought to understand how innovative procurement was viewed by different supply chain partners primarily including the main contractor, architect, material suppliers, and manufacturers. The case study approach followed the protocol developed in order to improve the validity of the research ${ }^{[25]}$. As a result, the research included a number of key elements such as clear and concise research objectives, research propositions, case study 
selection criteria, unit of analysis, a structured questionnaire, unstructured questionnaire for interview, a predetermined case study procedure, and an interview guide ${ }^{[25]}$. The study involved multiple visits to each organization involved, including an average of three interviews with the Managing Directors of these companies and other staff and a few other interviews which their supply chain members in North West of England. All interviews lasted for at least 1 hour. An assumed name for each company has been adopted for the purpose of confidentiality, when reporting the case studies.

Two of four case studies from the project are reported here. Both case studies explore the initiatives taken by a public sector client to motivate their supply chain participants in order to adopt innovative ways of working within a project team. The case studies especially focus on how suppliers and manufacturers are integrated as part of the innovative procurement strategies by clients.

Members of the senior management team of each of the abovementioned organizations including directors and senior managers were interviewed. Soft System Methodology (SSM), along with case study research method, was used to analyze the interviews, in order to conduct organizational analysis. For the social and organizational aspects, the research draws on contextually rich modeling techniques of $\mathrm{SSM}^{[26]}$ with its emphasis on a stream of cultural analysis within construction organizations, and the overall industry. SSM is selected because the research deals with the softer social issues and phenomena such as changes in the behavior of people and companies in response to the changes in procurement routes. Once the interviews were carried out, the data was compiled. It helped researchers identify the issues and areas which have been affected by the changes in procurement strategies. The root definitions and Client Activity Transformation Worldview Owner Environment (CATWOEs in SSM) related scenario was then developed from the initial compiled data which helped us to understand the transformation of past situations and circumstances into the present scenarios. Some of the results are reported in this paper as observations of changes due to the innovative procurement, and integrating issues affecting the adoption of innovative ways of working. 


\subsection{Case Study 1}

The first case study was done with a public client, a local council, having a portfolio to deliver new and/or refurbished public facilities to the residents. This includes refurbishments of social housing stock, building primary and secondary schools within the area, and, ... etc. through its in-house development team which acts as client by developing the specifications and allocating budget for different facilities. The council has developed a Framework Agreement to construct educational buildings (primary school in the first phase) in the value range of $£ 500,000$ to $£ 5 \mathrm{~m}$. For this client-led innovative and new way of developing educational infrastructure, which basically aims at the process of getting product developed, three Constructor Partners were appointed. Since the appointment, a number of educational projects have already been started and some of them are in the early stages of design. At the same time, the council is piloting to roll out framework agreements with manufacturers and suppliers whereby the standard products would be used all across the framework within all their projects. This would require change in organizational structure within the participating organizations because of the lead taken by the council through aggregation of their demand.

\subsubsection{Examples of Integration with Suppliers and Manufacturers}

- Glass manufacturer is being considered for framework agreement. The company is already supplying glass products for 22 projects. The company is targeting to spend $£ 1.25 \mathrm{~m}$ instead of $£ 2.5 \mathrm{~m}$ (50\% cheaper in price) by offering the council an excellent glazing package, if their product becomes standard for all the school projects developed and refurbished, by the council. The council is also determined to achieve cost savings by working alongside with architects and installers. Since, design determines the level of spending according to the glass manufacturers, their earlier involvement at the design stage has already brought $25 \%$ of savings in the past projects. Furthermore, more savings could be achieved during the life of the project through reduced operations and maintenance costs.

- For Steel work, the council works very closely with an organization, which is not only the manufacturer, but also carries out structural design and delivery of the material on-site. This organization 
has invested in its employees and developed robust long-term relationships with their regular clients including the council through very close collaboration on projects, right from the early stages. $80 \%$ of their business is coming from nine repeat clients for the last few decades and for them repeat business is the key. According to them, innovation brings savings and also gives competitive advantage over their competitors. According to their marketing director, continuous work with the council is resulting in continuous improvements within the services they offer and also rolling out into a framework agreement between this steel company and the council.

- Dynamic lights from a leading manufacturer are being used in primary school as a standard product. In this case, the council nominated the manufacturer based on their successful relationships in the past and introduced them to their Mechanical and Electrical (M\&E) contractor. For manufacturer, it was a good partnering experience where they themselves (also suppliers of their products) and M\&E contractors, all sat together and worked to deliver the M\&E services to the council. The above is a good example of integration of supply chain at downstream level within the supply chain facilitated by the client. It is important for the council to avail the specialist knowledge of the suppliers and manufacturers at the early stages of school project development and build long term relationship with them and provide them with work load certainty and commitment.

- Door supplier and manufacturer for the council, is a national company. The council is planning to develop a framework agreement with them as well, for standard product for their school's development. Similar to steel work organization, this company believes in partnering relationship and repeat business. On the other hand, they very much rely on inter-dependency with other supply chain partners. According to one of their directors, their early involvement in a project is the key because it would positively influence scheduling coordination, product standardization, optimized design, cost certainty, shared benefits and savings, and technical competences. The director also mentioned that the council is committed and the framework would be great for them because it would provide them with an environment to be creative and committed to the council, in order to deliver the best value as well as work together with other partners on the project. He also confirmed that initiatives by the council have challenged the way the industry thinks and behaves. 
- Brick supplier for the council is also keen to get involved at the design stage. They could bring with them standardized components and better investment of time and money if consulted early as part of framework partners, which in traditional process, could be done but without certainty of the contract award. They see communication as key, and support the idea of each supplier and manufacturer speaking to traders and installers of their product(s) as well as with clients who are developing specification, matching their products. For them too, repeat business is crucial resulting into savings because money is not spent for tendering to win contracts for the same client and therefore could be used in other areas within organizations such as marketing, sales, research and development, training, detailed design, ...etc.

\subsubsection{Discussion}

For the council, innovative procurement means: better relationship with the suppliers in order to reduce cost, have successful and quicker delivery of projects, good value for money, and fulfilling their requirement. In order to achieve efficiency and productivity targets set by the Government, the council is trying to integrate manufacturers and suppliers to their design process through innovative procurement routes. Their focus is to work towards design specifications and standardized products in consultation with architects, main contractors, regionallybased suppliers, and manufacturers. Having early involvement and good relationships with suppliers and manufacturers would result into manageable risks for the council; higher focus on the value and not on the price; learning, capturing, and sharing knowledge within projects; and delivery of sustainable projects through sustainable products. Other advantages include: affordable solutions; consistency of specifications in all projects across framework; consistency in design; projects are providing test beds for new products; client, stakeholders and end-users satisfaction; technical and cost certainty; continuous improvements (cutting cost through elimination of waste from the processes); product development to meet requirements; and reduction in lifecycle costs and maintenance of the products and projects. Some of the findings, mentioned below, show the commitment of the council towards their innovative way of procurement: 
- At the start of any project with the framework, all parties devoted time upfront to resolve design and buildability issues, resulting in savings in terms of cost and time.

- Council's driven initiative has resulted in sharing of knowledge and experiences on different platforms including management meetings as well as interest group meetings.

- Working in framework has resulted in good relationship-building with the council, and other supply chain participants.

\subsection{Case Study 2}

The second case study was conducted with a consortium of Local Authorities (LAs) and Registered Social Landlords (RSLs), having a portfolio to deliver refurbished social housing stock. The consortium has developed separate agreements with installers and suppliers/ manufacturers to provide services and products for their social housing stock in four work streams: door and windows, bathrooms, kitchens, and gas central heating. This clients-led innovative and new way of refurbishing of social housing stock has now become a national benchmark for LAs and RSLs. During the case study, only one work stream was studied; Gas Central Heating (GCH). Organizations involved within the supply chain of GCH work-stream were studied, and their employees interviewed. This supply chain has only two tiers; the first tier has the consortium and their consultants and the second tier has the installers and product suppliers / manufacturers.

\subsubsection{Examples of Integration with Suppliers and Manufacturers}

- Marketing director of a leading boiler company was interviewed which is selected supplier of boilers for the consortium through innovative procurement solution. He was very enthusiastic about the whole idea of partnering and supply chain integration because according to him Partnering brings: best value to the client; quality products fitted right first time with good standards and with low running cost; continuous dialogue among all parties, which will take inefficiency out of the whole process. According to the boiler manufacturer point of view, they need consistency of work load from the consortium in order to offer 
consistency of employment to their employees, specially the local people whom they hire. They use a term 'Work Smoothing' for the consistent work load. This would include information such as current pace of work, future orders, ... etc. This is needed so that the boiler manufacturers can incorporate those requirements in their supply and production plan. In return of specific lead time from the consortium, they are giving cost consistency for a specific period of time, as well as delivery of the products just-in-time.

- Radiator supplier and manufacturer (the same entity manufactures and supplied), selected in the same innovative ways as of the boiler supplier, was interviewed as a part of GCH work stream. According to them, the consortium members are now looking at stock availability, commitment of services level, whole life cost, when they communicate with them directly. But in the past, when contractors used to select the products for the consortium members, it was only based on the cheapest price, rebate, product supplier which gives more and longer period credit. At the same time, they are getting the predictability of demand from the consortium, so that they can streamline their production and reduce the wastage. Although their per project profit is less, the long term relationship results in significantly higher volume of business, and thus, a higher overall profit in the long term. At the same time, they are never guaranteed the volume but are guaranteed that complete demand will be given to them to supply for the consortium projects. Since LAs and RSLs are working together in one region as part of consortium, therefore, there are no conflicts and no problems in getting the material supply for their work stream.

\subsubsection{Discussion}

The suppliers and manufacturers are now in direct communication with clients, talking to them, demonstrating their products, and explaining about the installation, warranties and training. In the above mentioned case study, the consortium is getting the best value from suppliers and manufacturers because they are prepared to invest in partnership, by bringing innovation in their products and by subsidizing 
the prices. A couple of findings from the case studies are presented below, which echo the success story of innovative procurement process:

- Workforce smoothing (including hiring direct work force) within involved organizations within the supply chain through work load smoothing.

- Growth in supply chain partners as consortium activities grow in existing and new regions.

\section{Conclusions}

This paper presented two case studies, showing how different clients established their procurement processes through innovative thinking in management and integration of their supply chain. The case studies reveal the role of clients and their innovation procurement initiatives in order to integrate the supply chain participants within the construction industry.

Figure 1 shows the transformation of clients' role within a specific project development process. The construction industry is now moving towards the involvement of more and more informed clients, who are able to take the lead of their own project supply chains. This leadership has now seen a new era of integration and management of the supply chain through initiatives such as partnering, new procurement routes, supply chain policies and strategies, aggregation of demands, qualityprice tendering mechanism, and many other innovative initiatives

The case studies also suggest that supplier/manufacturer-client cooperation can act as a catalyst to promote innovative thinking and collaborative culture. The innovative procurement methods have resulted in the improvement of existing processes within the companies studied, and also resulted in development of innovative solutions by different manufacturers to different problems with an integrated approach. The findings also indicate that both clients and their innovative procurement methods can help promote the culture of integration within the industry.

The findings have also revealed some of the factors underpinning the motivation of those companies working within the new procurement environment, including both suppliers and manufacturers. This includes the continuity of work; transparent and open book accounting system 
which give added value to the clients; long term relationship; definite profit margin for a longer term period; visibility of the future work with the existing clients; overall growth of companies involved in terms of turnover and profit margin; job security for directly employed people; recognition as forward thinking clients within UK construction community through knowledge dissemination; training for staff employed by these companies as part of their skill enhancement program; and self-satisfaction from the quality work done and services provided.

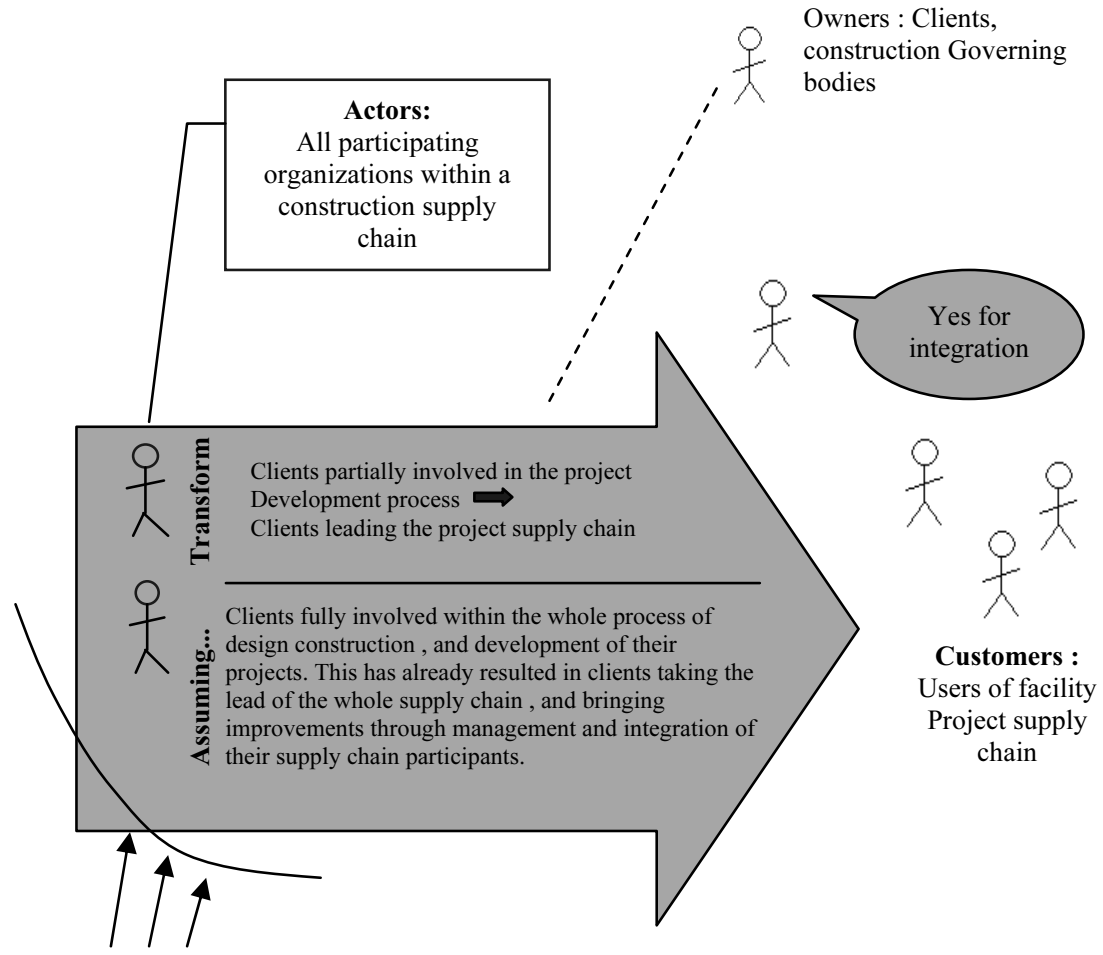

Environmental pressure on the activity:

Resistance to introduce and manage the integrated arrangements. Fragmentation within the construction project supply chain. Large number of points of contacts and tiers within the supply chain.

Fig. 1. An example of the transformation to client leading the supply chain within construction industry.

Fully informed and involved construction clients are working towards the management and integration of the whole supply chain participants. Clients achieving the integrated supply chains by leading the 
supply chains and bringing reforms through new procurement routes, policies, strategies, collaboration, clear communication.

The authors do believe that the most recent initiatives taken by client organizations to adopt key performance indicators (KPIs) in the near future could also contribute positively in the responses and attitude of supply chain partners towards the awareness and adoption of innovative procurement strategies. The readers would also be able to appreciate that during the course of the case studies, issues related to challenges and difficulties were also found, and some of those issues have been reported in this paper, but have not been discussed in detail because they were out of the scope of this paper and will be reported somewhere else. There is also a need to report on the findings from all the cases at the end of the project, which would reveal the in-depth and holistic view about the changes occurring in general due to innovative procurement within the industry on the one hand, and would also give perspectives of different participants involved within the construction supply chain including the suppliers and manufacturers.

\section{References}

[1] Khalfan, M.M.A. and McDermott, P. (2006) Innovating for supply chain integration within construction, Journal of Construction Innovation, 6: 143-157.

[2] Khalfan, M.M.A. and McDermott, P. (2007) Once unthought, now the best practice within construction industry, Journal of Construction Procurement (Under Publication).

[3] Eriksson, P.E., Dickinson, M. and Khalfan, M.M.A. ( 2006) Client-led subcontractor involvement - A way to increase value creation and innovation?, Construction in the $21^{\text {st }}$ Century: Local and Global Challenges, Joint 2006 CIB W65/W55/W86 symposium Proceedings, Pietroforte, R.; De Angelis, E. and Polverino, F. (ed.), Rome, Italy, 18-20 October 2006, CD ROM.

[4] Eriksson, P.E., Dickinson, M. and Khalfan, M.M.A. (2007) Partnering and procurement effects on subcontractor involvement and innovation, Facilities (Under Publication).

[5] Khalfan, M.M.A., Eriksson, P., Dickinson, M. and McDermott, P. (2006) Listening to the voices of suppliers and subcontractors!, $3^{\text {rd }}$ International SCRI Symposium, $3^{\text {rd }}-4^{\text {th }}$ April 2006, Delft, pp: 509-520.

[6] Latham, M. (1994) Constructing the Team, Final Report on Joint Review of Procurement and Contractual Agreements in the UK Construction Industry, HMSO, London.

[7] Egan, J. (1998) Rethinking Construction, The Report of the Construction Task Force on the Scope for improving the Quality and Efficiency of UK Construction. Department of the Environment, Transport and the regions, HMSO, London.

[8] Egan, J. (2002) Accelerating Change, A Report by Strategic Forum for Construction, London.

[9] Treasury, H.M. (1999) Achieving Excellence - Constructing the Best Government Client, HM Treasury.

[10] Report, O.G.C. (2003) Building on Success, Office of Government Commerce, London.

[11] Report, N.A.O. (2001) Modernizing Construction, The Stationary Office, London. 
[12] Report, N.A.O. (2005) Improving Public Services Through Better Construction, National Audit Office: 87, London.

[13] McDermott, P. and Khalfan, M.M.A. (2006) Achieving supply chain integration within construction industry, The Australian Journal of Construction Economics and Building, Vol. 6, (Under Publication).

[14] Swan, W. and Khalfan, M.M.A. (2007) Mutual Objective Setting for Partnering Projects in the Public Sector, Engineering, Construction and Architectural Management, 14(2): 119130.

[15] Bresnen, M. and Marshall, N. (2000) Building Partnerships: Case Studies of ClientContractor Collaboration in the UK Construction Industry, Construction Management and Economics, 18(7): 819-832.

[16] Bresnen, M. and Marshall, N. (2000) Partnering in Construction: A Critical Review of Issues, Problems \& Dilemmas, Construction Management and Economics, 18(2): 229-237.

[17] Bresnen, M. and Marshall, N. (2000) Motivation, Commitment and the Use of Incentives in Partnerships and Alliances, Construction Management and Economics, 18(5): 587-598.

[18] Chan, A., Chan, D. and Ho, K. (2003) An Empirical Study of the Benefits of Construction Partnering in Hong Kong, Construction Management and Economics, 21(5): 523-533.

[19] Ng, T., Rose, T., Mak, M. and Chen, S.E. (2002) Problematic Issues Associated with Project Partnering - The Contractor Perspective, International Journal of Project Management 20(6): 437-449.

[20] Packham, G., Thomas, B. and Miller, C. (2003) Partnering in the House Building Sector: A Subcontractor's View, International Journal of Project Management, 21(5): 327-332.

[21] Briscoe, G.H., Dainty, A.R.J., Millett, S.J. and Neale, R.H. (2004) Client-led strategies for construction supply chain improvement, Construction Management and Economics, 22 (2): 193-201.

[22] Pietroforte, R. (1997) Communication and Governance in the Building Process, Construction Management and Economics, 15(1): 71-82.

[23] Saad, M., Jones, M. and James, P. (2002) A Review of the Progress towards the Adoption of Supply Chain Management (SCM) Relationships in Construction, European Journal of Purchasing \& Supply Management, 8(3): 173-183.

[24] Dainty, A.R.J., Briscoe, G. H. and Millett, S. (2001) Subcontractor perspective of supply chain alliances, Construction Management and Economics, 19: 841-848.

[25] Yin, R.K. (1994) Case Study Research: Design and Methods, $2^{\text {nd }}$ ed. London: Sage Publications.

[26] Checkland, P., (1981) Systems Thinking, Systems Practice, Wiley, Chichester. 
تكامل الموردين و المصنعين في سلسلة توريد أعمال التشييد من خلال استر اتيجيات مبتكرة لتأمين المشتريات

مالكك م. خلفان، ومحمد عارف، وهاني م. أبوراس" جامعة سالفورد، مانشستر، المملكة الدتحدة، و"جامعة الملك عبدالعزيز، جدة، المملكة العربية السعودية

الكستخلص. إن المبادرات المبتكرة الحديثة ضمن مشتريات تثييد

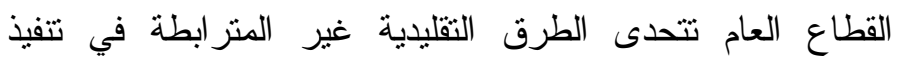

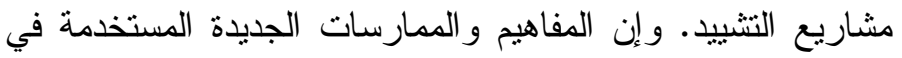
طرق المشتريات المبتكرة للتشييد يُقصد منها تفويض الزبائن

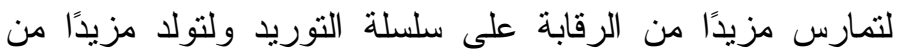

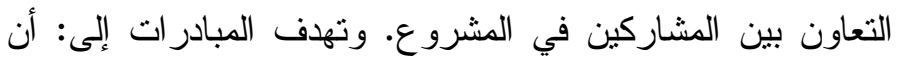
تزيد من تقارب أطراف المشروع من بعضهم البعض، وأن تكامل

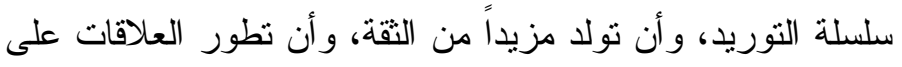

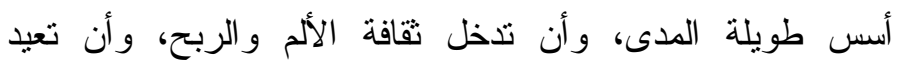

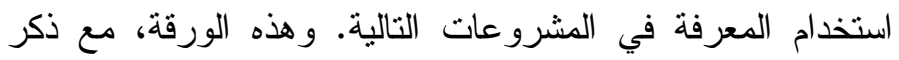

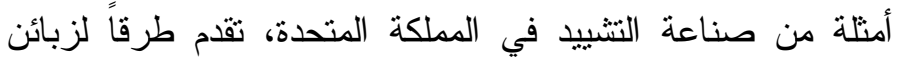
يمارسون حالياً أدو ارهم من أجل التكامل في اتجاه أعضاء سلسلة

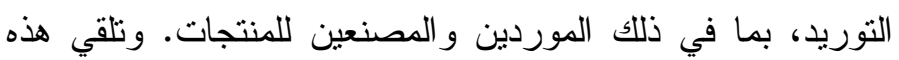

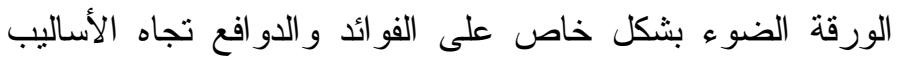
المبنكرة لتامين المشتريات والمؤدية إلى تكامل أعضاء سلسلة

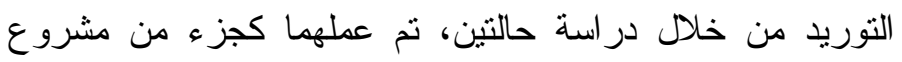

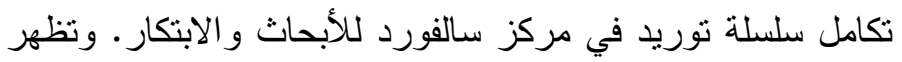
دراسات الحالة كيف عززت المنظمات المرتبطة التفكير الابتكاري 
عبر سلسلة التوريد من خلال التدابير الابتكارية. وكذلك ألقت در اسات الحالة هذه الضوء على بعض العو امل الحرجة في تكامل

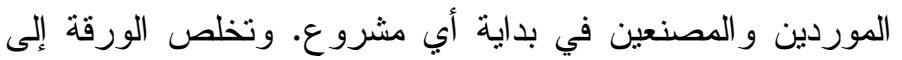

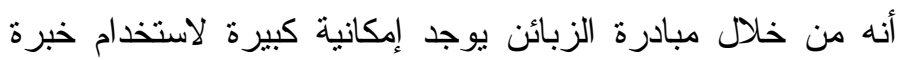

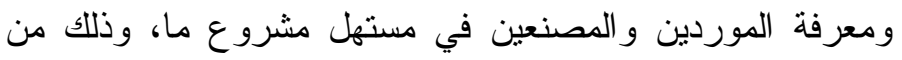

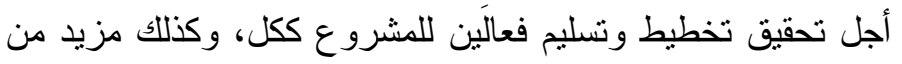

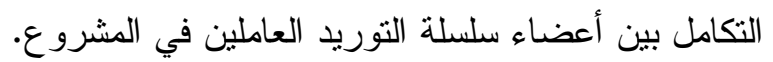
الكلمات الدالة: استراتيجيات المشتريات، تكامل سلسلة التوريد، الموردون و المصنعون، صناعة التشييد، الزبائن. 